\title{
PENDIDIKAN BERBASIS KELUARGA DALAM KITAB RUT BAGI PELAYANAN S2C DI GBI KELIR SAMARINDA
}

\author{
Novelia Palele ${ }^{* 1}$, Lina Triana ${ }^{2}$ \\ ${ }^{1,2}$ Sekolah Tinggi Teologi Bethel Samarinda \\ *novelianovel301197@gmail.com
}

\begin{abstract}
Theoretical basis: The family is a community that Allah has determined and defined for human needs. Research Objectives: (1) What is meant by family based education? (2) Why are some congregations lazy to follow Serving, and Confidant of God? (3) Why have some Serving, and Confidant of God congregations become discouraged? (4) What is the reason why some congregations refuse to follow Serving, and Confidant of God? (5) How is Family-Based Education and its application for Serving and Confidant of God services at GBI Kelir Samarinda? Method: Qualitative-Observative. Results of the study: (1) This education takes place in the family which is carried out by parents who are given to educate children in the family environment, (2) the congregation thinks the shepherd does not pay attention to it, the shepherd prefers the congregation, the congregation cannot keep secrets, the shepherd cannot be a good example. (3) Not comfortable attending worship, Thinking that this community is not important, Feeling just a waste of time, Worshiping too long. (4) Busy working, no desire to worship, rainy weather conditions, far distance to places of worship, do not have vehicles, do not have offerings for worship, there are conflicts among congregation members that have not been resolved. (5) through the communities of Salvation, Serving, and Confidant of God, we can reach out to every congregation in the church and through the communities of Salvation, Serving, and Confidant of God.
\end{abstract}

\section{Keywords: Education, Family, Service}

\begin{abstract}
Abstrak: Landasan teori: Keluarga adalah komunitas yang Allah telah tentukan dan tetapkan bagi kebutuhan manusia. Tujuan Penelitian: (1) Apakah yang dimaksud dengan Pendidikan Berbasis Keluarga? (2) Mengapakah beberapa jemaat malas mengikuti Serving, dan Confidant of God? (3) Mengapa beberapa jemaat Serving, dan Confidant of God menjadi tawar hati? (4) Apakah penyebab beberapa jemaat yang tidak mau mengikuti Serving, dan Confidant of God? (5) Bagaimanakah Pendidikan Berbasis Keluarga dan penerapannya bagi pelayanan Serving, dan Confidant of God di GBI Kelir Samarinda? Metode:KualitatifObservatif. Hasil Penelitian: (1)Pendidikan ini berlangsung dalam keluarga yang dilaksanakan oleh orang tua yang diberikan untuk mendidik anak dalam lingkungan keluarga, (2) jemaat menilai gembala tidak memerhatikannya, gembala pilih kasih kepada jemaat, jemaat tidak bisa menyimpan rahasia, gembala tidak bisa menjadi teladan yang baik. (3) Kurang nyaman mengikuti ibadah, Menganggap bahwa komunitas ini tidak penting, Merasa hanya membuang waktu saja, Ibadahnya terlalu lama. (4) Sibuk bekerja, Tidak ada kerinduan beribadah, Keadaan cuaca hujan, Jarak tempat beribadah jauh, Tidak mempunyai kendaraan, Tidak mempunyai persembahan untuk beribadah, Ada konflik sesama anggota jemaat yang belum diselesaikan. (5) melalui komunitas Salvation, Serving, dan Confidant of God dapat menjaungkau setiap jemaat-jemaat yang ada di gereja dan melaluin komunitas Salvation, Serving, dan Confidant of God.
\end{abstract}

Kata Kunci: Pendidikan, Keluarga, Pelayanan 


\section{PENDAHULUAN}

Keluarga adalah komunitas yang Allah telah tentukan dan tetapkan bagi kebutuhan manusia. Keluarga adalah tempat di mana Allah memberikan perintah untuk beranak cucu dan menguasai bumi serta terbangunnya kasih antara seorang pria dan wanita yang sepakat mengikat janji seumur hidup dan hanya maut yang dapat memisahkannya. ${ }^{1}$

Kitab Rut adalah salah satu kitab sejarah Perjanjian Lama yang awal kisahnya terjadi pada zaman Hakim-Hakim. Pada zaman para Hakim memerintah terjadi kelaparan di Israel. Lalu pergilah Elimelekh beserta Naomi dan anak-anaknya Mahlon dan Kilyon. Setelah mereka sampai di Moab, tinggalah mereka di sana, kemudian matilah Elimelekh suami Naomi ini sehingga hanya anak-anaknya saja yang menemani Naomi. ${ }^{2}$

Pada saat membaca kitab Rut akan ditemukan suatu pengajaran di dalam sebuah keluarga yaitu tentang kesetiaan. kesetiaan manusia dalam keluarga sangat dituntut agar semua orang dapat berelasi dengan baik dengan orang lain bahkan dengan anggota keluarganya sendiri. Contohnya yaitu keluarga besar dari Elimelekh, Naomi, dan kedua anaknya yaitu Mahlon dan Kilyon. ${ }^{3}$

Pendidikan kitab Rut yang dapat diteladani dari kehidupan Rut perempuan saleh dari Moab yang menikah dengan seseorang yang berbeda baik kepercayaan dan latar belakangnya yaitu Rut menunjukkan kasih setianya kepada mertuannya Naomi. Di tengah kehidupan Rut sebagai seorang asing ia semakin percaya kepada Tuhan Allah Israel dan memilih tetap ikut dengan mertuanya yaitu Naomi yaitu kembali ke Yehuda dari pada ia tinggal di Bangsanya sendiri. Rut tidak meninggalkan Naomi. ${ }^{4}$

${ }^{1}$ King Anderonikus Rorong, Keluargaku Surgaku (Bandung: Kalam Hidup, 2008), 10.

${ }^{2}$ Saparman, Kupasan Firman Allah

Kitab Rut (Bandung: Yayasan Baptis Indonesia, 2003), 16-18.

${ }^{3}$ Harianto GP, Teologi PAK (Yogyakarta: Andi, 2017), 153.

34 | Vol. 2 No. 2 (Juli-Desember 2018)
Dalam kehidupan Kristen pernikahan antara suami istri bertugas untuk mewakili gambar persatuan antara Kristus dengan gereja-Nya melalui pengorbanan diri sendiri, kepatuhan dan kesetiaan. Sebagai keluarga Kristen baik suami maupun istri berhak menuntut kesetiaan pasangannya karena keluarga Kristen tidak diciptakan untuk kepentingan sendiri tetapi keluarga Kristen diciptakan untuk saling melengkapi dan membawa kemuliaan bagi Allah sehingga keluarga mengalami kebahagiaan dalam Yesus Kristus. $^{5}$

Dalam keluarga sangat dibutuhkan persekutuan dengan Tuhan yang akan membuat setiap anggota keluarga tidak terpengaruh dengan keadaan dunia modern yang membawa kepada kemerosotan moral. Peter Wagner mengatakan pada bukunya, orang-orang Kristen sedang menghadapi kegelapan yang semakin meningkat dalam masyarakat sekarang ini. ${ }^{6}$

Ibadah dalam komunitas Sel melalui GBI Keluarga Imamat Rajani yang dikenal dengan nama Salvation, Serving, dan Confidant of God. Ibadah Salvation, Serving, dan Confidant of God merupakan salah satu program yang baik untuk meningkatkan kualitas kerohanian jemaat. Dalam setiap anggota akan memiliki interaksi dengan anggota lainnya dalam daerah tertentu. ? Dalam komunitas Salvation, Serving, dan Confidant of God Setiap anggota didorong untuk melayani, memberikan yang terbaik bagi Tuhan dan anggota Salvation, Serving, dan Confidant of God bukan hanya sekedar untuk mengikuti ibadah saja, melalui Salvation, Serving, dan Confidant of God ini anggota jemaat juga menjadi jemaat yang

${ }^{4}$ Peniel C. D. Maiaweng dan Christina Ukung. (2018). "Apakah Rut, Perempuan Moab adalah Penyembah Tuhan". Jurnal Jaffray, 16, 163-164.

${ }^{5}$ Larry Christenson, Keluarga Kristen (Semarang: Yayasan Persekutuan Betania, 1970), 7-8.

${ }^{6}$ Peter Wagner, Kebutuhan Gereja Saat Ini (Malang: Gandum Mas, 2001), 40.

${ }^{7}$ Joel Comiskey, Ledakkan Kelompok Sel (Jakarta: Metanoia, 1998), 19. 
berakar, bertumbuh dan berbuah dalam komunitas Salvation, Serving, dan Confidant of God sehingga jemaat menjadi jemaat yang setia kepada Tuhan. ${ }^{8}$

Dari uraian teori-teori berikut ditemukan di lapangan pelayanan Salvation, Serving, dan Confidant of God di GBI Keluarga Imamat Rajani Samarinda ditemukan fenomena-fenomena sebagai berikut: (1) Ditemukan beberapa jemaat yang malas mengikuti Serving, dan Confidant of God, (2) Ditemukan beberapa anggota Serving, dan Confidant of God yang tawar hati, dan (3) Ditemukan beberapa jemaat yang tidak mau mengikuti Serving, dan Confidant of God.

Solusi terhadap problem tersebut perlu dijawab dengan kerja penelitian yang bertujuan: (1) Apakah yang dimaksud dengan Pendidikan Berbasis Keluarga? (2) Mengapakah beberapa jemaat malas mengikuti Serving, dan Confidant of God? (3) Mengapa beberapa jemaat Serving, dan Confidant of God menjadi tawar hati? (4) Apakah penyebab beberapa jemaat yang tidak mau mengikuti Serving, dan Confidant of God? (5) Bagaimanakah Pendidikan Berbasis Keluarga dan penerapannya bagi pelayanan Serving, dan Confidant of God di GBI KelIR Samarinda?

\section{PEMBAHASAN}

\section{Pengertian Pendidikan Berbasis Keluarga}

Pendidikan adalah usaha sadar dan terencana untuk mewujudkan proses pembelajaran agar peserta didik secara aktif mengembangkan potensi dirinya sehingga memiliki kekuatan spiritual keagamaan, dan moral. ${ }^{9}$ Sedangkan menurut Harianto GP, Pendidikan adalah proses perubahan cara pikir atau tingkah laku melalui pengajaran, penyuluhan, dan latihan. ${ }^{10}$ Pendidikan adalah

${ }^{8}$ Lerry Stockstill, Gereja Sel: Mempersiapkan Gereja Menghadapi Masa Penuaian (Jakarta: Metanoia, 2000), 53.

${ }^{9}$ W.R.F. Browning, Kamus Alkitab A Dictionary of the Bible (Jakarta: Gunung Mulia, 2007), 324.

${ }^{10}$ Harianto GP, Teologi PAK, 72. proses pengubahan sikap dan tata laku seseorang atau kelompok orang dalam usaha mendewasakan manusia melalui upaya pengajaran dan pelatihan, proses, cara, dan perbuatan mendidik. ${ }^{11}$

Keluarga adalah orang seisi rumah yang menjadi tanggungan. ${ }^{12}$ Sedangkan menurut King Anderonikus bahwa keluarga adalah kelompok manusia yang memiliki sifat dan tujuan yang sama, baik positif maupun negative. ${ }^{13}$ Keluarga adalah konsep modern keluarga, yang terdiri dari ayah dan ibu yang dipersatukan seumur hidup dalam pernikahan. ${ }^{14}$ Lebih dalam Harianto GP mngatakan bahwa pendidikan keluarga adalah pendidikan yang dimulai dari keluarga. Anak harus dididik dan didorong untuk menerapkan semua nilai luhur sebagaimana diajarkan firman Tuhan dan dijauhkan dari segala hal yang dilarang. Hal yang penting adalah orangtua sebagai pendidik wajib memiliki kerohanian yang berkualitas dan terampil mendidik anak-anaknya dalam Tuhan. ${ }^{15}$

Dari uraian di atas dapat disimpulkan bahwa Pendidikan Keluarga adalah pendidikan dan keluarga yang tidak dapat dipisahkan dimana ada keluarga maka akan ada juga pendidikan didalam keluarga itu. Didalam keluarga terdapat anggota keluarga yang terdiri dari ayah, ibu, dan anak. Pendidikan ini berlangsung dalam keluarga yang dilaksanakan oleh orang tua yaitu ayah dan ibu sebagai tanggung jawab yang diberikan untuk mendidik anak dalam lingkungan keluarga sehingga terpenuhinya kebutuhan spiritual melalui penanaman nilainilai keagamaan.

Lebih dalam lagi pendidikan keluarga dalam kitab Rut dapat diuraikan sebagai berikut: Definisi Pendidikan Berbasis keluarga berdasarkan Kitab Rut adalah Rut

${ }^{11}$ Hasan Alwi, Kamus Besar Bahasa Indonesia (Jakarta: Balai Pustaka, 2001), 263.

${ }^{12}$ Ibid.536.

${ }^{13}$ King Anderonikus Rorong, Keluargaku Surgaku, 20.

${ }^{14}$ W.R.F. Browning, Kamus Alkitab A Dictionary of the Bible, 188.

${ }^{15}$ Harianto GP, Pendidikan Agama Kristen \& Dunia Pendidikan Masa Kini (Yogyakarta: Andi, 2012), 69-70.

Excelsis Deo: Jurnal Teologi, Misiologi, dan Pendidikan | 35 
1:16 Tetapi kata Rut: “janganlah desak aku meninggalkan engkau dan pulang dengan tidak mengikuti engkau; sebab ke mana engkau pergi, ke situ jugalah aku pergi, dan dimana engkau bermalam, di situ jugalah aku bermalam: bangsamulah bangsaku dan Allahmulah Allahku". Kata "kata" dalam Bahasa Ibrani (amar) yang memiliki arti mengatakan, berbicara, mengucapkan, menjawab. Jadi waktu itu Rut berbicara tentang mengatakan sesuatu. particle preposition suffix 1st person common singular. Kata "meninggalkan" dalam Bahasa Ibrani עָָָׁ (azab) yang memiliki arti untuk pergi, untuk pergi dari, membiarkan, ditinggalkan.

Definisi Pendidikan berbasis keluarga dalam kitab Rut 1:16 adalah dimana terjadinya suatu pengajaran yaitu antara Rut menantunya dengan mertuanya yang bernama Naomi. Dimana Rut menyatakan kesetiaannya kepada mertuanya yaitu Naomi dengan setia Rut sepanjang hidupnya tetap setia kepada Naomi walaupun suami Rut telah meninggal tetapi Rut tetap mau bersama dengan Naomi bahkan Rut tidak sekalipun meninggalkan Naomi.

Berdasarkan uraian diatas penulis menyimpulkan bahwa ketika Rut berbicara kepada MertuannyaYaitu Naomi bahwa Rut tidak akan membiarkan Naomi sendirian bahkan Rut tetap setia kepada Naomi untuk bersama-sama dengan Naomi bahkan ke mana pun Naomi pergi Rut dengan setia mengikutinya.

Solusinya ketika Rut mengambil keputusan bahwa Rut tidak akan meninggalkan Naomi maka hubungan Rut sebagai menantu dengan mertuannya yaitu Naomi menjadi suatu hubungan yang baik yang ditunjukan melalui kesetiaan Rut kepada Naomi Mertuanya. Dampaknya melalui kesetiaan Rut terhadap mertuannya yaitu Naomi adalah hubungan Rut dengan Naomi sangat baik mereka saling mengasihi antara satu sama lain tidak ada masalah yang terjadi antara Rut dan Naomi sehingga kehidupan mereka berdua diberkati oleh Tuhan.

Hasil wawancara dan observasi tentang "Bagaimanakah penerapan Pendidikan Berbasis Keluarga bagi pelayanan S2C GBI KelIR Samarinda ?" dapat diuraikan dalam tabel sebagai berikut:

\section{Tabel 1 PenyebabJjemaat Malas Mengikuti Serving, dan Confidant of God}

\begin{tabular}{|l|l|}
\hline Fokus & Sub Fokus \\
\hline Mengapakah beberapa & 1. Sibuk bekerja. \\
\cline { 2 - 2 } jemaat malas mengikuti & 2. Tidak ada kerinduan beribadah. \\
\cline { 2 - 2 } Serving, dan Confidant of & 3. Keadaan cuaca hujan. \\
\cline { 2 - 2 } & 4. Jarak tempat beribadah jauh dari rumah jemaat. \\
\cline { 2 - 2 } & 5. Tidak mempunyai kendaraan. \\
\cline { 2 - 2 } & 6. Tidak mempunyai persembahan untuk beribadah. \\
\cline { 2 - 2 } & 7. Gembalanya kurang pendekatan. \\
\cline { 2 - 2 } & 8. Ada konflik sesama anggota jemaat yang belum diselesaikan. \\
\hline
\end{tabular}

Dari hasil wawancara dan observasi terhadap 15 partisipan dalam tabel tersebut dapat diuraikan bahwa yang membuat jemaat malas mengikuti ibadah Serving, dan Confidant of God dikarenakan: sibuk bekerja, tidak ada kerinduan beribadah, keadaan cuaca hujan, jarak tempat beribadah jauh dari rumah jemaat, tidak mempunyai kendaraan, tidak mempunyai persembahan untuk beribadah, gembalanya kurang pendekatan, dan ada konflik sesama anggota jemaat yang belum diselesaikan.

\section{Tabel 2 Jemaat Serving, dan Confidant of God Menjadi Tawar Hati}

\begin{tabular}{|l|l|}
\hline Fokus & Sub Fokus \\
\hline \multirow{2}{*}{$\begin{array}{l}\text { Mengapakah beberapa } \\
\text { jemaat Serving, dan }\end{array}$} & 1. Jemaat merasa tidak diperhatikan gembala. \\
\cline { 2 - 2 } $\begin{array}{l}\text { Confidant of God menjadi } \\
\text { tawar hati? }\end{array}$ & 2. Gembala pilih kasih kepada jemaat. \\
\cline { 2 - 2 } & 3. Jemaat tidak bisa menyimpan rahasia. \\
\cline { 2 - 2 } & 4. Gembala tidak bisa menjadi teladan yang baik. \\
\hline
\end{tabular}




\section{Adanya jemaat bersifat egois.}

Dari hasil wawancara dan observasi terhadap 15 partisipan dalam tabel tersebut dapat diuraikan bahwa yang membuat jemaat tawar hati mengikuti ibadah Serving, dan Confidant of God dikarenakan: jemaat merasa tidak diperhatikan gembala, gembala pilih kasih kepada jemaat, jemaat tidak bisa menyimpan rahasia, gembala tidak bisa menjadi teladan yang baik, dan adanya jemaat yang bersifat egois.

Tabel 3 Jemaat yang tidak mau Mengikuti Serving, dan Confidant of God

\begin{tabular}{|c|c|}
\hline Fokus & Sub Fokus \\
\hline \multirow{5}{*}{$\begin{array}{l}\text { Apakah penyebab beberapa } \\
\text { jemaat yang tidak mau } \\
\text { mengikuti Salvation, Serving, } \\
\text { dan Confidant of God? }\end{array}$} & 1. Kurang nyaman mengikuti ibadah. \\
\hline & $\begin{array}{l}\text { 2. Menganggap bahwa komunitas ini tidak } \\
\text { penting. }\end{array}$ \\
\hline & 3. Merasa hanya membuang waktu saja. \\
\hline & 4. Jemaat takut untuk pelayana diibadah S2C. \\
\hline & 5. Ibadahnya terlalu lama. \\
\hline
\end{tabular}

Dari hasil wawancara dan observasi terhadap 15 partisipan dalam tabel tersebut dapat diuraikan bahwa yang membuat jemaat tidak mau mengikuti ibadah Serving, dan Confidant of God dikarenakan: kurang nyaman mengikuti ibadah, Menganggap bahwa komunitas ini tidak penting, merasa hanya membuang waktu saja, jemaat takut untuk pelayanan di ibadah Serving, dan Confidant of God, ibadahnya terlalu lama.

\section{Beberapa Jemaat Malas Mengikuti Serving dan Confidant of God}

Menurut penulis beberapa jemaat malas mengikuti Serving, dan Confidant of God adalah karena sebagai jemaat yang belum bertumbuh melalui Komunitas Serving, dan Confidant of God ini, sehingga tidak mempunyai kesadaran yang besar bahwa pentingnya Komunitas Serving, dan Confidant of God ini khususnya dalam keluarga sehingga apa yang terjadi di dalam keluarga dapat saling didiskusikan melalui komunitas Serving, dan Confidant of God ini sehingga jemaat yang ada tidak mempunyai alasan lagi untuk malas mengikuti Serving, dan Confidant of God seperti dengan alasan sibuk bekerja, tidak ada kerinduan beribadah, keadaan cuaca hujan, jarak tempat beribadah jauh dari rumah jemaat, tidak mempunyai kendaraan, tidak mempunyai persembahan untuk beribadah, gembalanya kurang pendekatan, dan ada konflik sesama anggota jemaat yang belum diselesaikan.

Di komunitas seperti ini juga sering ditemukan jemaat yang malas untuk mengikuti komunitas Serving, dan Confidant of God sehingga ditemukan berbagai macam alasan jemaat untuk tidak mengikuti Serving, dan Confidant of God ini. Sebab itu didalam komunitas ini Gembala yang telah dipercayakan untuk memimpin komunitas ini harus benar-benar gembala yang mau dan mempunyai hati yang mampu membawa jemaat untuk tidak malas mengikuti komunitas Serving, dan Confidant of God, Gembala harus mendorong dan memberikan motivasi kepada jemaat yang masih malasmalas mengikuti komunitas Serving, dan Confidant of God ini sehingga tidak ada lagi alasan bagi jemaat komunitas Serving, dan Confidant of God untuk malas mengikuti ibadah komunitas ini. Berkaitan Daniel Sutoyo mengatakan bahwa ketika jemaat mau bertumbuh melalui komunitas Serving, dan Confidant of God maka melalui komunitas ini jemaat dapat bertumbuh menuju kepada kedewasaan rohani sehingga tidak ada rasa malas yang membuat sebagian jemaat malas mengikuti komunitas Serving, dan Confidant of God. Karena melalui komunitas Serving, dan Confidant of God ini. Dimana jemaat tersebut bisa saling mendorong, saling menolong, saling mengasihi, dan saling mendoakan antara satu sama lain antara anggota atau pengurus Serving, dan Confidant of God dengan anggotanya. ${ }^{16}$

${ }^{16}$ Daniel Sutoyo, (2012), "Komunitas Kecil sebagai Tempat Pembelajaran Hidup Excelsis Deo: Jurnal Teologi, Misiologi, dan Pendidikan | 37 


\section{Jemaat Serving, dan Confidant of God Menjadi Tawar Hati}

Menurut penulis jemaat Salvation, Serving, dan Confidant of God yang tawar hati adalah jemaat yang masuk dalam perkumpulan komunitas Serving, dan Confidant of God tetapi di dalam komunitas tersebut ketika jemaat ini diperhadapkan dengan suatu masalah atau terjadinya perbedaan-perbedaan pikiran atau pendapat di dalam kelompok komunitas Serving, dan Confidant of God ini maka jemaat yang imannya masih lemah dengan adanya masalah ini yang terjadi mungkin antara sesama anggota Serving, dan Confidant of God atau atau kepada Gembalanya sehingga jemaat tersebut berfikir bahwa anggota atau jemaat dimana orang ini membangun komunitas di dalamnya merasa bahwa dia tidak dihargai seperti merasa tidak diperhatikan gembalanya, gembala pilih kasih kepada jemaat, jemaat tidak bisa menyimpan rahasia, gembala tidak bisa menjadi teladan yang baik, dan adanya jemaat yang bersifat egois.

Dari masalah-masalah inilah yang sering terjadi di dalam komunitas Serving, dan Confidant of God sehingga jemaat yang merasa tidak diperhatikan dan bisa menjadi jemaat yang tawar hati kepada Gembalanya atau kepada sesama anggota Serving, dan Confidant of God ini. Hal-hal inilah yang sering terjadi di dalam perkumpulanperkumpulan komunitas ini sehingga ketika ada jemaat yang imannya belum kuat maka dia akan merasa bahwa dia seperti orang yang diasingkan padahal bukan seperti itu hanya pikiran dewasanya yang belum membuat dia mengerti akan hal seperti ini.

Ketika diperhadapkan dengan hal ini sebaiknya jangan langsung berfikir hal-hal yang negatif seperti tidak diperhatikan gembala, gembala pilih kasih kepada jemaat, jemaat tidak bisa menyimpan rahasia, gembala tidak bisa menjadi teladan yang baik, dan adanya jemaat yang bersifat egois, melalui komunitas ini masalah-masalah seperti di atas inilah yang harus didiskusikan di dalam perkumpulan-perkumpulan komunitas ini sehingga jemaat yang merasa tawar hati bisa

Kristen”, Jurnal Antusias 2(1), 1. mengerti bahwa ternyata dia bukan orang yang diasingnya tetapi imannya saja yang belum kuat sehingga ketika ada masalah dia bisa mengerti.

Inilah fungsinya kenapa suatu gereja harus mempunyai komunitas-komunitas seperti ini karena ketika jemaat hanya mengikuti ibadah-ibadah di hari minggu rasanya kurang cukup karena hanya bernyanyi dan mendengarkan firman saja dan sulit untuk saling mengenal antara jemaat-jemaat yang ada apalagi untuk gereja-gereja yang besar dan memiliki banyak jemaat. Oleh karena itu gereja sangat berperan penting untuk membuka suatu komunitas yaitu seperti Salvation, Serving, dan Confidant of God. Melalui komunitas inilah jemaat bisa saling mengenal bisa saling cerita setiap masalahmasalah yang terjadi didalam kehidupan jemaat tersebut dan melalui komunitas inilah jemaat semakin bertumbuh dewasa secara rohani sehingga masalah-masalah apa yang ada jemaat mampu menyelesaikannya dan tidak ada lagi jemaat yang tawar hati.

Bagi gembala juga yang khususnya dipercayakan untuk menjadi pemimpin dalam komunitas ini harus juga mempunyai hati yang terbuka yang mau mendengarkan jemaat untuk cerita tentang setiap masalah-maslah yang dihadapi di dalam kehidupannya bahkan didalam keluarganya.

\section{Jemaat tidak Mau Mengikuti Salvation, Serving, dan Confidant of God}

Menurut penulis jemaat Salvation, Serving, dan Confidant of God yang tidak mau mengikuti Serving, dan Confidant of God adalah jemaat yang merasa tidak mendapatkan apa-apa melalui komunitas Serving, dan Confidant of God ini. Di dalam komunitas Serving, dan Confidant of God ini. Gembala komunitas harus mempunyai strategi yang sesuai dengan kondisi keadaan yang dibutuhkan sebagian jemaat yang tidak mau mengikuti komunitas Serving, dan Confidant of God sehingga strategi yang yang dibuat sesuai dengan apa yang jemaat inginkan khususnya bagi jemaat yang tidak mau mengikuti komunitas Serving, dan Confidant of God. Padahal melalui komunitas ini sebenarnya sangat dibutuhkan hari-hari ini 
ditegah-tengah jemaat yang belum mempunyai waktu atau menganggap komunitas ini tidak penting.

Ada pula jemaat tidak mau mengikuti komunitas Serving, dan Confidant of God dikarenakan jemaat merasa kurang nyaman mengikuti komunitas ini sehingga dihari-hari berikutnya jemaat tersebut tidak mau lagi untuk datang mengikuti komunitas Serving, dan Confidant of God ini dan hanya mau mengikuti ibadah-ibadah yang ada dihari minggu saja padahal ibadah dihari minggu belum cukup sempurna untuk membawa kehidupan jemaat semakin bertumbuh secara kedewasaan rohani sehingga melalui komunitas inilah jemaat bisa bertumbuh dewasa secara rohani yang dalam komunitas ini tidak terlalu banyak orang sehingga jemaat dapat saling share tentang kehidupan jemaat.

Ada juga yang menganggap bahwa komunitas Serving, dan Confidant of God adalah komunitas yang tidak penting dan merasa bahwa komunitas Serving, dan Confidant of God hanya membuang-buang waktu saja. Jemaat yang befikiran seperti ini adalah jemaat yang kurang bertumbuh kedewasaan rohaninya. Ada juga jemaat merasa takut untuk mengikuti komunitas Serving, dan Confidant of God.

Dikarenakan jemaat takut disuruh pelayanan seperti berdoa, memimpin pujian. Jemaat seperti ini harus diberikan penjelasan sehingga rasa takut untuk ditunjuk pelayanan dapat dikontrol karena ada jemaat yang mau mengikuti komunitas Serving, dan Confidant of God tetapi kendalanya adalah jemaat tersebut belum siap untuk mengambil pelayanan di komunitas Serving, dan Confidant of God ini sehingga membuat dirinya merasa takut, muncul pemikiranpemikiran bahwa jemaat tersebut tidak bisa berdoa atau memimpin pujian.

Karena itu Gembala yang dipercayakan untuk memimpin komunitas ini sebaiknya membuat jadwal-jadwal di jauhjauh hari sehingga jemaat yang tipe seperti ini tidak lagi merasa takut ketika tiba-tiba ditunjuk untuk berdoa atau memimpin pujian jadi ketika adanya jadwal-jadwal seperti ini jemaat tidak lagi merasa takut untuk ditunjuk memimpin di dalam komunitas Serving, dan
Confidant of God ini. Dan melalui cara seperti ini jemat tidak lagi mempunyai alasan untuk tidak mengikuti komunitas Serving, dan Confidant of God. Setiap jemaat yang ada semuanya tidak mempunyai pemikiraan yang sama dengan jemaat yang lain.

Ada juga jemaat yang tidak mau mengikuti komunitas Serving, dan Confidant of God karena ibadanya terlalu lama. Jadi sebagai Gembala komunitas Serving, dan Confidant of God harusnya juga bisa memperhatikan jam-jam ibadahnya dan tidak mengadakan ibadah di dalam komunitas ini dengan waktu yang lama. Komunitas seperti inilah harus benar-benar dijaga sedikit waktu yang dipakai sangat cukup yang penting membuat jemaat bisa mengerti poin-poin apa yang dimaksudkan dari pembacaan firman bahkan ketika ada anggota jemaat yang mau bersaksi melalui kesaksian itu jemaat yang merasa kelamaan ibadahnya bisa termotivasi.

Menurut Obaja Tanto Setiawan mengatakan bahwa jemaat yang tidak mau mengikuti komunitas Salvation, Serving, dan Confidant of God adalah jemaat yang tidak mau melibatkan diri untuk beribadah dalam komunitas Salvation, Serving, dan Confidant of God. Bahkan ada jemaat yang belum menyadari betapa pentingnya mengikuti ibadah komunitas Salvation, Serving, dan Confidant of God.

Dengan anggapan bahwa mengikuti komunitas Salvation, Serving, dan Confidant of God adalah hanya membuang-buang waktu saja. Sehingga jemaat ini hanya mau hadir di ibadah-ibadah hari minggu saja. Padahal didalam komunitas Salvation, Serving, dan Confidant of God inilah ada prinsip mejadi murid, dimuridkan dan memuridkan sehingga selalui komunitas ibadah Salvation, Serving, dan Confidant of God jemaat merasa bahwa penting hari-hari ini jemaat mengikuti komunitas ibadah Salvation, Serving, dan Confidant of God. ${ }^{17}$

17 Obaja Tanto Setiawan, Kelompok Sel Prinsip 12 (Solo: GBI Keluarga Allah, 2000), 59. 


\section{KESIMPULAN}

Berdasarkan hasil dari penelitian serta pembahasan diatas maka dapat disimpulkan dari penelitian yang diperoleh adalah pendidikan berbasis keluarga berdasarkan kitab Rut adalah mengajarkan tentang sebuah kesetiaan anatara seorang menantu dengan mertuanya dimana hubungan seperti ini sangat penting dibangun dalam setiap keluargakeluarga yang ada bahkan hubungan antara anggota keluarga yang lainya sehingga terus ada kesetiaan dalam setiap keluarga yang ada. Dalam komunitas Salvation, Serving, dan Confidant of God juga sangat penting untuk diterapkan di gereja-gereja yang ada saat ini. Karena melalui komunitas Salvation, Serving, dan Confidant of God dapat menjaungkau setiap jemaat-jemaat yang ada di gereja dan melaluin komunitas Salvation, Serving, dan Confidant of God jemaat bisa lebih bertumbuh secara rohani karena melalui komunitas ini jemaat diajarkan untuk saling mempedulikan dan saling melengkapi dalam kasih antara anggota jemaat Salvation, Serving, dan Confidant of God dengan sesama anggota Salvation, Serving, dan Confidant of God dan dapat diajak untuk terlibat dalam pelayananpelayanan komunitas Salvation, Serving, dan Confidant of God. Sehingga tidak ada lagi jemaat yang malas, tawar hati, dan tidak mengikuti Salvation, Serving, dan Confidant of God. Melaui komunitas Salvation, Serving, dan Confidant of God ketika jemaat melalukan dengan setia maka damai sejaterah akan terus ada dalam kehidupan bahkan terutama dalam keluarga.

\section{DAFTAR PUSTAKA}

Alwi, Hasan. Kamus Besar Bahasa Indonesia. Jakarta: Balai Pustaka, 2001.

Browning, W.R.F. Kamus Alkitab A Dictionary of the Bible. Jakarta: Gunung Mulia, 2007.

Christenson, Larry. Keluarga Kristen.

Semarang: Yayasan Persekutuan Betania, 1970.
Comiskey, Joel. Ledakkan Kelompok Sel. Jakarta: Metanoia, 1998.

GP, Harianto. Pendidikan Agama Kristen \& Dunia Pendidikan Masa Kini. Yogyakarta: Andi, 2012.

GP, Harianto. Teologi PAK. Yogyakarta: Andi, 2017.

Maiaweng, Peniel C. D. dan Christina Ukung. (2018). "Apakah Rut, Perempuan Moab adalah Penyembah Tuhan". Jurnal Jaffray, 16, 163-164.

Rorong, King Anderonikus. Keluargaku Surgaku. Bandung: Kalam Hidup, 2008.

Saparman. Kupasan Firman Allah Kitab Rut. Bandung: Yayasan Baptis Indonesia, 2003.

Setiawan, Obaja Tanto. Kelompok Sel Prinsip 12. Solo: GBI Keluarga Allah, 2000.

Stockstill, Lerry. Gereja Sel: Mempersiapkan Gereja Menghadapi Masa Penuaian.Jakarta: Metanoia, 2000.

Sutoyo, Daniel. (2012). "Komunitas Kecil sebagai Tempat Pembelajaran Hidup Kristen”, Jurnal Antusias, 2(1), 1.

Wagner, Peter. Kebutuhan Gereja Saat Ini. Malang: Gandum Mas, 2001. 